\title{
Utilization of Cultural Heritage Complex of the Tomb of the Kings of Hadat Banggae as a Tourist Destination Object in MajeneRegency West Sulawesi
}

\author{
Khadijah Thahir Muda $^{1}$, Yusriana Yusriana ${ }^{2}$, Nur Ihsan D. ${ }^{3}$ \\ 1,2,3 Archaeology Department Faculty of Cultural Sciences Universitas Hasanuddin \\ * Corresponding author. Email: khadijah@unhas.ac.id
}

\begin{abstract}
The Tomb Complex of the Kings of Hadat Banggae (hereinafter will be written KM Raja-rajaHadat Banggae) is believed to be a burial complex for kings and members of the Hadat councilof the kingdom of Banggae. The Hadat Banggae Council emerged during the reign of Daeng Tamilanto (Mara'dia Banggae II or the 2nd king). The figure of Daeng Tamilanto is said to have developed the kingdom's territory by embracing traditional leaders (Tomakaka) around him. Utilization of open space by people who engage in open area activities. this activity is often uncontrolled and can damage the Cultural Heritage objects in the Tomb Complex of theKings of Hadat Banggae. The qualitative approach carried out in this study was combined witha search of historical data literature and those related to KM Raja-raja Hadat Banggae as well as interviews with community leaders, visitors, residents, KM Site maintainers.
\end{abstract}

Keywords: Preservation, Utilization, Graves, Cultural Heritage Objects

\section{INTRODUCTION}

The province of West Sulawesi ranked 33rd as the newest province formation in 2004, Majene Regency is one of the six regencies in West Sulawesi. namely Polewali Mandaar (Polman), Mamasa, Majene, Mamuju, North Mamuju (Polinggomang, 2015). Administratively, KM Rajaraja Hadat Banggae is located in Pangali-Ali Village, Banggae District, Majene Regency, West Sulawesi Province.Access to the site can be reached by passingthrough a residential road as far as \pm 850 meast of the Majene Regent's Office.

Astronomically, the site is located at the coordinates of $3^{\circ} 32^{\prime} 31.6^{\prime \prime}$ South Latitude and $118^{\circ} 57^{\prime} 44.7^{\prime \prime}$ East Longitude with an altitude of 46 $\mathrm{m}$ above sea level and directly opposite Mandar Bay. The site is located inan open area bordered by plantations in thenorth, east and south by ravines (sea), and in the west by residential areas and public cemeteries. The total area of the tomb complex is $10,589 \mathrm{~m} 2$.

The influence of Islamic symbols isvery large in this Mandar Land, it can be seen that the influence of Islamic culture has colored all sides of their lives. The Kingdom of Banggae (Majene) received Islamic influence around 1608, beginning with the arrival of Sheikh Abdul Mannan toTanah Mandar, Majene, who was then KingTomatindo di Masigi, and succeeded in converting Sukkilan, one of the maradia (king) of the Kingdom of Banggae [1].

This site has been researched several times, including a survey in 1981 by Abdul Muttalib, in 1994 by Darmawan Mas'ud et. al. The research is directed at thetypology of tombs and tombs. In 1999 the tomb complex was designated as a site withinventory number 151 based on the Decreeof the Minister of Education and Culture Juwono Sudarsono no. 240/M/1999 on October 4, 1999. Based on data from Disparbud Majene, the restoration was carried out twice, namely in 19871988 and1988-1990. Furthermore, in 2014 zoning was carried out by the Makassar Cultural Heritage Preservation Center. Conservation activities were carried out in the same year, but at that time, 
conservation was directed at tombs and gravestones made of stone (Haeruddin et al, 2014). Currently, KM Raja-raja Hadat Banggae has been used as a tourist attraction. In KM Raja-raja Hadat Banggae there are 480 ancient tombs.

This ancient tomb complex does not only consist of ancient tombs, there are several new tombs, at certain times new tombs are added, and it was discontinued in 1985. The difference between new tombs and ancient tombs is still recognizable.

In general, the technique of makingtombs is known to be a cross-linked technique (pairs connected) arranged in layers to the top and has a support pole thathas a hole as a place to attach pegs to the wall whose ends will be pegged at each corner and have stone or wooden tombstones. There is also a monolith tombmade of monolith stone carved in such a way that it is square. There is a hole at the top for mounting the headstone.

\section{METHODS}

The application of a qualitative approach to research related to the study ofthe Law on Cultural Conservation in terms of the preservation and utilization of Cultural Conservation objects. The implementation begins with searching library data, relating to cultural history and relating to preservation.

The implementation of this research uses archaeological research methodsincluding starting with the data collection stage to complete a detailed site description, analysis and interpretation of interview data on-site maintainers, visitors, and residents around the site. The archaeological survey carried out is a systematic survey to collect field data with activities in the form of inventory, measurements, depictions, mapping, and descriptions of the tomb complex and its environment.

\section{DESCRIPTION OF THE TOMBS COMPLEX OFTHE KINGS OF HADAT BANGGAE}

Administratively, KM Raja-rajaHadat Banggae is located in the Pangali-alineighborhood, PangaliAli Village, Banggae District, Majene Regency, West Sulawesi Province. Access to the site can be reached by passing through a residential road as far as $\pm 850 \mathrm{~m}$ east of the Majene Regent's Office. Astronomically, the site is located at the coordinates of $3^{\circ} 32^{\prime} 31.6^{\prime \prime}$ South Latitude and $118^{\circ} 57^{\prime} 44.7^{\prime \prime}$ East Longitude with an altitude of 46 $\mathrm{m}$ above sea level and directly opposite Mandar Bay.The site is located in an open area bordered by plantations in the north, east and south by ravines (sea), and in the west by residential areas and public cemeteries. Thetotal area of the tomb complex is $10,589 \mathrm{~m} 2$. This site has been researched several times, including a survey in 1981 by Abdul Muttalib, in 1994 by Darmawan Mas'ud et al. The research is directed at the typology of tombs and tombs. In 1999 the tomb complex was designated as a site with inventory number 151 based on the Decree of the Minister of Education and Culture Juwono Sudarsono no.240/M/1999 on October 4, 1999. Based on data from the Majene Disparbud, the restoration was carried out twice, namely in 1987-1988 and 1988-1990. Furthermore, in 2014 zoningwas carried out by the Makassar Cultural Heritage Preservation Center. Conservation activities were carried out in the same year,but at that time, conservation was directed at the jirat and tombstones of graves made of rock. Currently, KM Raja-raja HadatBanggae has been used as a tourist attraction [2]

From the aspect of tomb decoration, this complex is very rich in decoration and calligraphy. The recognizable decorative motifs include tendrils, flora (leaves and flowers), geometric motifs, banji and stripes. On some headstones, there are calligraphy inscriptions, inscribed with thecreed by carving on the tombstone. Most ofthem are damaged and weathered. The tomb complex is divided into four sectors that have been determined by previous researchers. 68 wooden tombstones were found. The position of the tombstone consists of two types, one is plugged directly into the ground or plugged into a hole in the tomb rock. A total of 52 headstones were plugged directly into the ground, while 16 other headstones wereplugged into holes in the gravestones.

The tombs are made entirely of stone, totalling 412 tombs. The condition ofeach grave is different. Based on observations, it is known that stone tombs also experience damage and weathering, both mechanical damage, physical weathering, and biotic damage. a) Mechanical Damage Laying factors and dynamic forces that impinge on objects are factors that cause mechanical damage. The results of observations at the tomb complexshowed that the tomb suffered mechanical damage in the form of cracks, fractures, and shifted from its original position. b) Physical weathering Symptoms of physicalweathering are observed by the presence ofcracks and wear on the surface of the tomb.

c) Biotic Weathering is caused by the activities of living things, namely fungi, mosses, and plants. Biotic weathering is triggered by conditions ofhigh rainfall and humidity. Observations showed that the biotic weathering that occurred in stone graves was caused by the growth of mosses and wild plants. Based onobservations, several stone tombs located around large trees such as ketapang trees that are protected from direct sunlight, havea higher level of biotic weathering when compared to stone tombs exposed to directsunlight. 


\subsection{The Raw Material of The Tombstone}

This tomb complex has tombs that are entirely made of stone, some tombs on jirat and gravestones consist of stone, and the tombstone is made of wood. Experiencing damage and weathering, bothcaused by internal factors such as the quality of wood materials and external factors such as climate, andbiodeterioration (damage to materials due to living things). According to Trisna Priadi(2005) [3], the existence of biological wooddestroying factors is quite large as a cause of inefficiency in the processing and utilizationof this wood. Tropical temperature in Indonesia is a temperature that triggers various biological destroying factors, both in number and type. Furthermore, Trisna Priadi in his research on the biodeterioration of wood components, saidthat two factors make wood biodegradable, making it susceptible to being infected by wood-destroying organisms made from lignocellulosic materials, which are nutrients for organisms such as fungi, termites. wood is a growing medium, shelter and breeding ground for these organisms [4].

The expansion and shrinkage caused by temperature can change the physical properties of the rock material. The expansion or thermal movement can produce a force strong enough to causecracks [5]. Building cracks can be caused by two things: first, there is a displacement of the centre of gravity of several building components so that gravity transfers occur to achieve a new balance, and second, it is caused by a decrease in the bearing capacityof the soil under the structure. The form of cracks due to the movement of the buildingstructure is usually large at the top and smoother at the bottom. In addition, uncontrolled human activities can cause themost fatal damage to Cultural Conservation.

\section{DISCUSSION}

\subsection{Significance of religious, history, cultural education and science}

Following the purpose of preservation, the essence is to maintain the Significant Values of CulturalConservation so that they are not lost or reduced [2]. Some experts and practitionersbelieve that the measurement of the Important Value of cultural resources can and should be carried out objectively, standardly, systematically, and even quantitatively or statistically, but other parties tend to hold the view that cultural resources are inherently unique and therefore must always be considered to have Important Value before being provenunimportant [6].

After the assessment and determination of the Important Values of cultural resources is very much needed because the Important Values are strong and dominant, it will be a benchmark when deciding matters related to cultural resources [7] concluding recommendations regarding steps or attitudes for cultural resources will be conserved, destroyed, modified or leftalone [5]. Important Value Analysis is to determine the steps to be taken before determining the type of designation of a Cultural Conservation site or Cultural Conservation area. The stage of determining the Important Values becomesvery strategic because the results will become a benchmark for determining the stages that will be determined in the next management process. If there is no attitude for determining Important Values, it will not be able to determine actions or for its restoration and preservation.

Significant Values related to Cultural Conservation legislation, arefactors that ensure a material cultural heritage to be designated as a Cultural Conservation. Therefore, the study of the Important Values of material cultural heritage is the determining factor carried out in the process of determining it as a Cultural Conservation. Conceptually and theoretically, to assess the existence of cultural heritage, there are several conditions as having been thought by several experts. Schiffer and Gummerman [8] described the six important values used to conduct the assessment, namely, theimportance of science, the importance of history, the importance of ethnicity, the importance of public values, the importanceof law and the importance of funding [7]. In the Importance of Science, Schiffer and Gumerman [8] define it as cultural heritage if it has the potential to be further investigated in answering problems in the scientific field. Furthermore, the ImportantValue of History according to Schiffer andGumerman [8], can be assessed from the ability of cultural heritage to witness human life both in prehistoric times, history, and those related to certain events that contain important history. A cultural heritage that is related to the history of science can also be included in this requirement. Important Ethnic Values, the assessment is based on the ability of cultural heritage to provide an understanding of the social, religious, and mythological background of a particularnation. Public Importance Value, determined by the benefits of cultural heritage in providing education to the community about the past and its research procedures, enriching knowledge about human existence today, for recreational facilities, and its ability to increase income for the community through tourism activities. Legal Importance Values, the assessment is determined based on the guidelines set out in certain laws relating tocultural heritage. The Importance of Funding needs to be done because it relates to the consideration of whether the costs that will be used to handle cultural heritageare by the aspects of the benefits 
of the cultural heritage. However, this important value in terms of funding often creates problems and controversies, so it tends to be ignored. Although theformulation compiled by Schiffer and Gumerman is quite complete, several otherexperts add. Snyder and Catanese provide six benchmarks, namely; Rarityrefers to rare works that are not owned by other regions. The value of rarity or uniqueness can also be based on the availability of cultural heritage, where the more limited a cultural heritage is, the higher its value; Aesthetics, considered based on the elements of art contained in the cultural heritage, which includes the beauty of the shape, structure and ornamentof the building; History, concerning the location of important historical events; Superlativity, in the sense of oldest, highestor longest; Pluralism, a building is a typicalwork, representing a certain type or variety of buildings; and Quality of Influence, namely its existence can improve the imageof the surrounding environment [7].

Tanudirjo [9] proposesguidelines for Important Values to explain the Important Values contained in the legislation, which are as follows. a. Historical Importance Values, if these cultural resources can be valuable evidence of events that occurred in prehistoric and historical times, are closely related to historical figures or are the remains/works of prominent figures in certain fields, or become evidence of important developments in certain fieldssuch as discoveries, application of new technologies, and social, economic and political changes. b. The Importance of Science, if the cultural resources have the potential to be studied further to answer problems in certain scientific fields. The scientific field in question does not only cover the social field but also relates to the field of non-social science. Each of these fields of science has its own goals. The following is an overview of some fieldsof science along with their objectives. Archeology describes, explains andanswers problems related to events or cultural processes in the past, including testing certain theories, methods, and techniques in this field. Anthropology, to study the general principles in this field, inparticular the processes of cultural change in the long term and processes of ecological adaptation, including biological evolution and palaeoanthropology. This criterion is to accommodate the possibility of a cultural resource containing information for science that usually does not intersect at all with the past, so it is predictive. c. Important Cultural Values, if these cultural resources can represent the results of certain cultural achievements, encourage the process of creating culture, or become the cultural identity of a particular nation or community. For example, ethnic values provide an understanding of the background of social life, belief systems, and mythology, all of which are the identity of a particular nation or community. Aesthetic value, containing elements of beauty both related to fine arts, decorative arts, building arts, sound arts and other art forms, including harmony between landscapes and cultural works (saujana culture); become a useful source of inspiration aimed at producing cultural works now and in the future. Furthermore, public value also has the opportunity to be increased as a medium for public education about the past and its research process; remind about human existence now; has the potential or has become a recreational facility; and has the potential or has becomea resource that can increase people's income, one of which is in the tourismsector [6].

Furthermore, after discussing the Important Values in the legislation related to Cultural Conservation, it shows how these Important Values are decisive in determining the next steps to be taken on the Cultural Conservation objects that havebeen studied. The site of the Tomb of the Kings of Hadat Banggae, which has been assessed based on Important Values, has complied with the criteria or requirements set for Important Values.

The important historical value of the Ancient Tombs of the Kings of Hadat Banggae has is from the history associated with Majene Regency, the majority tribe inthis Regency is the Mandar Tribe. The Banggae Kingdom is one of the kingdoms incorporated into the Mandar Pitu Ba'banaBinanga confederation state or commonly called the seven estuaries of the river declared in Tammajarra in 1580 AD.

The Tomb Complex of the Tombs of the Kings of Hadat Banggae has an important scientific value because it can be the object of research in developing science. In terms of architecture, the Tombof the Kings of Hadat Banggae has design features in the form of various forms of tombs, either in terms of manufacture or architecture, ornaments attached to the tomb, have characteristics that are quite different from the ancient tombs of the same time and located elsewhere.

The tombs of the Kings of Hadat Banggae can be a medium of learning, especially in the art of building design. Application of technology on tombstones (jirat) to connect the stones to form the desired tomb, with stone peg technology, and arrange tombstones. can beseen how the balance of technology and artdevelops here, which can be observed.

Important values of culture becomea discussion to see how far the site of the ancient tombs of the kings of HadatBanggae is associated with culture, then will be included ethnicities related to the Mandar Tribe. 


\subsection{Cultural Conservation Utilization and Legislation}

It will be an interesting discussion if the utilization related to Cultural Conservation Objects is linked. Because, in the Cultural Conservation Law, utilization is one of the criteria in the implementation of conservation. Regarding the utilization of cultural heritage, it has been regulated inthe Cultural Conservation Law no. 11 of 2010 in article no 86-88, that every cultural heritage can be utilized by the Government, Local Government, and everyone for the benefit of religion, social, education, science, technology, culture, andtourism. If the benefits are considered to cause damage, it must be preceded by a study, research, and /or analysis of environmental impacts.

\subsection{Utilization for Cultural Tourism and Pilgrimate Tourism}

The government's attitude in responding to Cultural Conservation objects that must be managed as publicfacilities must be carried out as a form of responsibility. This is reflected in the website KM Raja-Raja Hadat Banggae, in collaboration with BPCB SULSELRA, has managed it well. For the preservation of ancient tombs which after being studiedbased on Important Values are considered very worthy to be the pride of the people ofMajene Regency.

This site has become a cultural tourism destination for the people ofMajene. It is proven by the increasing number of visits. The visitors are not only from Majene Regency but also from other regencies in West and South Sulawesi (interview with Idham, 2021). This site is also a religious tourism destination, because of the results of interviews with visitors who come to visit the graves. The existence of this site after the restoration awakens a new spirit for the community. The local people'semotions from those who do not think there are to be amazed, and proud. The restoration has made the people of Majene Regency who have visited this site the emotions that were generated, namelybeing proud to have a historic cultural heritage, supported by sea views from Majene Bay, and a neat garden [11].

The number of visitors who come to this site, with various interests is quite large, based on data from the guest book on the KM Raja-raja Hadatbanggae website, 2019 there were 7,351 people and in 2020 there was a decrease in the number of visitors who came to 5,082 people. The decline in the number in the following yearwas due to the Covid 19 pandemic which limited gathering and visiting public places, to prevent the spread of the Covid 19 disease.

But on the other hand, the preservation of cultural heritage related to tourism, the local government still has to pay attention to, besides being concerned with the economic value, it must also pay attention to the value of its preservation because the two can go hand in hand. This must be considered to utilize Cultural Conservation objects, they must be treated in a measured and careful manner considering the non-renewable nature of Cultural Conservation Objects. Our joint task is to educate the public as owners of shared culture to participate in preserving the site's sustainability.

The intrinsic value of Cultural Conservation besides containing academic and educational potential and value also contains aesthetic and exotic potential and value that can be developed to support Cultural Conservation as a tourist attraction. People who use the Tomb of theKings Hadat Banggae Complex Site as a tourist destination, both cultural and religious tourism, must take care of it. Thiscontent can be used as a "spirit" in theutilization of Cultural Conservation related to tourism. The uniqueness, rarity, splendour, beauty, and complexity of this noble work are some of the aesthetic and visual exotic values of Cultural Conservation. The utilization of Cultural Conservation as a tourist attraction has a reciprocal relationship. Positive exploitation of the site as a Cultural Conservation object should as much as possible support aspects of object preservation. Among them are developing the appreciation of visitors at this site for the ancestral cultural heritage and the cultural meanings it contains [11].

To develop tourism activities in Cultural Conservation locations, certain strategies are needed. Several aspects must be considered in determining the next step in the development of this activity. Starting from planning, policymaking at the local government level, direct community participation by utilizing the resources and values of wisdom possessed. The concept of structuring the Cultural Conservation environment for tourism activities without eliminating aspects of preservation and protection.

Ideally, an effort to seek the management of tourism activities involving Cultural Conservation objects as destinations, by maximizing public facilities, the environment, and security forboth the Cultural Conservation object sitesand the public as visitors. Because good service and education for the people who visit are not easy for the government, but things must continue to be carried out as a form of responsibility.

The party most responsible as a bridge that must be able to connect all aspects and integrate supporting resourcesin tourism activities is the local government. Local governments must be observant in understanding, mapping the strengths and 
weaknesses of their tourism resources. This foundation becomes propriety for local governments to act before issuing a policy that becomes a guideline in the implementation of tourismactivities.

The treatment of vandalism is foundin 14 ancient tombs, writing using paint, there are writings on how to carve writing using sharp tools on the tomb. At the time of making the tomb, giving decorative motifs to the tomb area, usually by measuring with a tool hitting technique, if the force is excessively excessive, small cracks will occur that are not visible. These cracks make the strength of the material easier to place in places of destroying fauna and flora. Utilize open land as a place to play kites.

\section{CONCLUSION}

The existence of the Tomb Complexof the Kings of Hadat Banggae is the pride of the people of Majene Regency, when thissite still has not received attention from thegovernment, the condition of this site has not been neatly arranged, it can be said that it is a group of ancient tombs that have notreceived any attention from the government or the public. After undergoing restoration and having been arranged neatly, evoke different emotions, a sense of pride, admiration, and will look for a common thread of the history of the site with him, or the history of the area where the site is located.

Based on the study of the Significant Values attached to the Tomb ofthe Kings of Hadat Banggae Complex, the management, preservation, and utilization of this site must continue to be carried out optimally without reducing caution in the use of this site both as a tourist destination and as a research forum.

Because there is still a lot of vandalism that occurs in the tomb area,among others, by crossing out, engraving names on the tomb using sharp tools, throwing trash out of place. This is a joint task for the government to educate the public to jointly maintain the preservation of this site.

\section{REFERENCES}

[1] Poelinggomang, Edward L. (2015). Sejarah Mandar (Masa Kerajaan hingga Sulawesi Barat). Solo: Zahadaniva.

[2] Kawu, Abd Shadiq. (2011). Sejarah Masuknya Islam di Majene.Jurnal AlQalam Vol 7. No.2.

[3] Priadi, Trisna. (2005). 15 January 2005 Pelapukan Kayu Oleh Jamur Dan Strategi Pengendaliannya. Makalah pribadi Pengantar Falsafah Sains (PPS702) Sekolah Pasca Sarjana/S3Institut Pertania Bogor.

[4] Tokede, J. Max. B.V. Mambai, L.V. Pangkali, Z. Mardiyadi, (2013). Antara Opini dan Fakta
Kayu Merbau Jenis Niagawi Hutan Tropika Papua Primadona Yang Dikhawatirkan Punah.www.fsc.org.

[5] Pearson, M dan S. Sullivan. (1995). Looking After Heritage Places: The Basic of Heritage Planning for Managers, Landowners and Adiministrators. Melbourne: Melbourne University Press.

[6] Schaafsma, Curtis F. (1990). SignificantUntil Proven Otherwise: Problems Versus Representative Samples, in H. F. Cleere (ed.), Archaeological Heritage Management in The Modern World. London. UnwinHyman. Hal. 38-50

[7] H. F. Cleere (ed.), Archaeological Heritage Management in The Modern World. London. Unwin-Hyman. Hal. 38-50

[8] Schiffer, Michael B. \& George J. Gummerman. (1977). Conservation Archaeology, A Guide for CulturalResources Management Studies . London: Academic Press New York SanFransisco.

[9] Tanudirjo, DA. (2004). Penetapan Nilai Penting Dalam Pengelolaan Benda Cagar Budaya, Makalah dalam Rapat Penyusunan Standardisasi Kriteria (Pembobotan) Bangunan Benda Cagar Budaya di Rumah Joglo Rempoa, Ciputat, Jakarta, 26 - 28 Mei 2004.

[10] Kriswandono,A. dan Nurtjahja Eka Pradana, (2014). Sejarah dan Prinsip Konservasi Arsitektural Bangunan Cagar Budaya Nasional. Institut Konservasi Ermit. Semarang.

[11] Fitri, Dhea Wardani. (2020). Pemanfaatan Cagar Budaya untuk Pariwisata in http://kebudayaan.kemdikbud.go.id/bpc bsumbar/pemanfaatan-cagar-budaya- untukpariwisata/. 